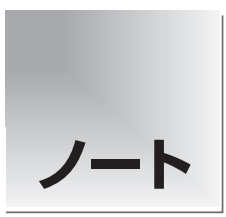

論文受付

2012 年 12 月 14 日

論文受理

2013 年 5 月 12 日

Code No. 431

\section{複数の治療計画装置を用いた 前立腺 IMRT 計画の比較検討}

\author{
佐々木幹治 ${ }^{1}$ 生島仁史 ${ }^{2}$ 中口裕二 ${ }^{3}$ 岸 太郎 ${ }^{1}$ \\ 木村雅司 ${ }^{1,5}$ 坂東良太 ${ }^{1}$ 筇田将皇 ${ }^{4}$ \\ 1 徳島大学病院放射線部 \\ 2 徳島大学大学院保健科学教育部医用情報科学領域 \\ 3 熊本大学医学部附属病院医療技術部 \\ 4 岡山大学大学院保健学研究科 \\ 5 現 筑波大学附属病院放射線腫瘍科
}

\section{緒 言}

強度变調放射線治療(intensity modulated radiation therapy: IMRT)とは, 治療計画装置(radiation treatment planning systems: RTPS)によって最適化されたビーム群 を複数の方向から照射し, 標的に高線量を照射すると 同時にその周囲の正常組織への線量軽減を図ることが できる治療方法である。マルチリーフコリメータ (multileaf collimator: MLC)を用いた IMRT では，極小で複雑 な形状に区分された照射野(リーフセグメンテーション)
を断続的 (segmental MLC-IMRT: SMLC-IMRT)もしくは 連続的 (dynamic-MLC-IMRT: DMLC-IMRT)に形成し線 量強度をそれぞれの区分された照射野で変化させて照 射する方法が多く用いられている1,2). 現在, MLCを用 いた IMRTは，各社にて実装されているがMLCのリー フセグメンテーション作成方法および治療計画線量計 算アルゴリズムは異なることが知られている ${ }^{3 \sim 5)}$. 過去 の報告では，多施設による複数の RTPSを用いた計画 標的体積(planning target volume: PTV)の最低線量, 平

\title{
A Comparison of Four Commercial Radiation Treatment Planning Systems for Prostate Intensity Modulated Radiation Therapy
}

\author{
Motoharu Sasaki, ${ }^{1 *}$ Hitoshi Ikushima, ${ }^{2}$ Yuji Nakaguchi, ${ }^{3}$ Tarou Kishi, ${ }^{1}$ \\ Masashi Kimura, ${ }^{1,5}$ Ryouta Bandou, ${ }^{1}$ and Masataka Oita ${ }^{4}$ \\ ${ }^{1}$ Department of Radiology, Tokushima University Hospital \\ ${ }^{2}$ Graduated School of Health Science, University of Tokushima \\ ${ }^{3}$ Department of Radiological Technology, Kumamoto University Hospital \\ ${ }^{4}$ Graduated School of Health Science, University of Okayama \\ ${ }^{5}$ Current address: Department of Radiation Oncology, University of Tsukuba
}

Received December 14, 2012; Revision accepted May 12, 2013

Code No. 431

\section{Summary}

At present, every manufacturer of intensity modulated radiation therapy (IMRT) equipment uses multileaf collimators (MLCs); however, each company's intensity modulation methods and dose calculation algorithms differ. This study used four typical radiation treatment planning systems (RTPSs) employed domestically for prostate IMRT plans to carry out 15 case studies by one planner based on the dose limits at this clinic. The results were used to compare the differences, if any, in RTPS treatment plans. With prostate IMRT plans, an overlap area exists between the PTV and the rectum. For this reason, while observing dose limits of 60-75 Gy (within the dose tolerated by the rectum), securing uniformity and concentration of dose is essential to create the most appropriate treatment plan for the PTV and other targets. Although each RTPS uses different planning methods, it was generally possible to observe this clinic's dose limits by adjusting the parameter values. When identical beam data is used, it is possible to create similar treatment plans.

Key words: intensity modulated radiation therapy (IMRT), radiation treatment planning systems (RTPS), prostate cancer

*Proceeding author 
均線量, 最大線量およびリスク臓器 (organs at risk: OAR)への線量などの比較を行ったものがある ${ }^{6,7)}$.

Fogliata らによる報告6)では 4 名の同一小児腫瘍患者を 複数の RTPS によって計画を行ったうえで評価を行って いるが，研究の再現を行ううえで，治療計画パラメー夕 設定の記載が不足している報告である。.Dasらによる報 告7)では，各々の計画については少なくとも50 例以上 IMRT 計画を行った経験者によって施行されているが, 肝心の処方線量の決定方法は記載されておらず，対象 患者も異なるため一定の評価を行うことは困難である. さらに，これら二つの過去の報告は，いずれも多施設で 行われた結果であるため標的およびリスク臓器の輪郭 描出の統一性がないことが考えられ，線量制約につい ても評価基準が曖昧であるため客観性にそしいことが 考えられる。その他，過去に同一の放射線治療装置に よる IMRT 計画を複数の RTPS を用いて行った報告は 少なく, 同一の計画者によって立案された計画の報告 はない，そこで，本研究では前立腺 IMRT の計画を国 内で使用されている代表的な 4 社の RTPS を用いて，統 一された線量制約に基づき 1 人の計画者によって 15 症 例行った，限定的な条件ではあるが，当院の線量制約を 満たすように治療計画を行った際に，異なる RTPS 間で 違いが生じるかについて検討することを目的とした。

\section{1. 使用機器および対象}

RTPS に登録したビームデー夕は $15 \mathrm{MV}-\mathrm{X}$ 線を発す る NovalisTx (BrainLAB 社製)である. NovalisTx に搭載 されている MLC は，中心 32 対のリーフ幅が $2.5 \mathrm{~mm}$, 両端 28 対 が $5 \mathrm{~mm}$ の 120-leaf high-definition MLC (HD120MLC)である. RTPS とその計算アルゴリズムに は, Eclipse ver.8.9.17(Varian 社製) analytical anisotropic algorithm(AAA), Pinnacle ver.9.0 (Philips 社 製) collapsed cone superposition 法, XiO ver4.6.2(ELEKTA 社製) convolution 法, iPlan ver.4.1.2(BrainLAB 社製) pencil beam 法を用いた。 各 RTPS の IMRT 計画手法は, Eclipse とiPlan は DMLC-IMRT, Pinnacle とXiOは SMLC-IMRT とした. なお, 本研究の $\mathrm{XiO} て ゙$ convolution 法を採用したのは，過去の治療成績による妥当性と計 算時間を考慮したものである。放射線治療装置は，装 置個々でビーム特性が異なるためユーザ責任において 線量測定を実施し, 臨床使用可能であるか確認するこ とが必須であるとされている8 各RTPSに登録されたビームデータは, American Association of Physicists in Medicine(AAPM)Report No.559)に従って，あらかじめコミッショニングを行った 臨床使用に問題のないデータを用いて行っている。対
Table 1 Patient characteristics

\begin{tabular}{ccc}
\hline \hline & $\mathrm{n}$ & $\%$ \\
\hline Tumor Stage & & \\
T1c & 6 & 40.00 \\
T2c & 1 & 6.67 \\
T3a & 8 & 53.33 \\
PSA & & \\
$\leq 10$ & 6 & 40.00 \\
$10<-<20$ & 4 & 26.67 \\
$20 \leq$ & 5 & 33.33 \\
Gleason score & & \\
$\leq 6$ & 3 & 20.00 \\
7 & 6 & 40.00 \\
$8 \leq$ & 6 & 40.00 \\
Risk & & \\
Low risk & 2 & 13.33 \\
Intermediate risk & 7 & 46.67 \\
High risk & 6 & 40.00 \\
\hline
\end{tabular}

PSA: prostate-specific antigen

象は，過去に当院で前立腺 IMRT を行った 15 症例とし た，各症例の詳細については, Table 1 に示す。なお, 治療計画においては診療過程で過去に得られたデー夕 であり，個人情報の保護や利益相反の管理を考慮し， 研究を目的としたデー夕利用する可能性があることにつ いて患者に説明を行い，同意・承認を得て臨床的研究を 実施した。治療計画用 computed tomography $(\mathrm{CT})$ に は，4列マルチスライスCT Asteion TSX021A/3J(東芝 社製)を使用し，管電圧 $120 \mathrm{kV}$, field of view(FOV)： $500 \mathrm{~mm}$ 再構成スライス厚 $2.5 \mathrm{~mm}$ で撮影した。 いずれ の RTPS についても不均質補正を考慮し，計算グリッド サイズは $2 \times 2 \times 2 \mathrm{~mm}$ として計算を行った。

\section{2. 方 法}

\section{2-1 治療計画に使用する構造体の描出 \\ 2-1-1 輪郭定義}

後述する当院の輪郭描出プロトコルに従って, 放射 線治療専門医によって腫瘍(前立腺＋精囊)および OAR の描出を行った。臨床標的体積 (clinical target volume: CTV)は，前立腺と精囊の一部を足し合わせた体積とし た。また，精囊の一部の描出方法については，前立腺 から $2 \mathrm{~cm}$ 拡大した体積の中に含まれる精囊を CTV と している[Fig. 1(a)]. CTV から背面部とそれ以外の全 方向に，それぞれ $6 \mathrm{~mm}$ と $8 \mathrm{~mm}$ のマージンを設定し PTV とした，直腸の体積については，radiation therapy oncology group(RTOG)のガイドライン10)では，坐骨結 節から下行結腸と直腸間にある $\mathrm{S}$ 状結腸までの領域も しくは, $15 \mathrm{~cm}$ までの領域となっている。しかし，輪郭 描出者間による差異をできるだけ少なくするために 

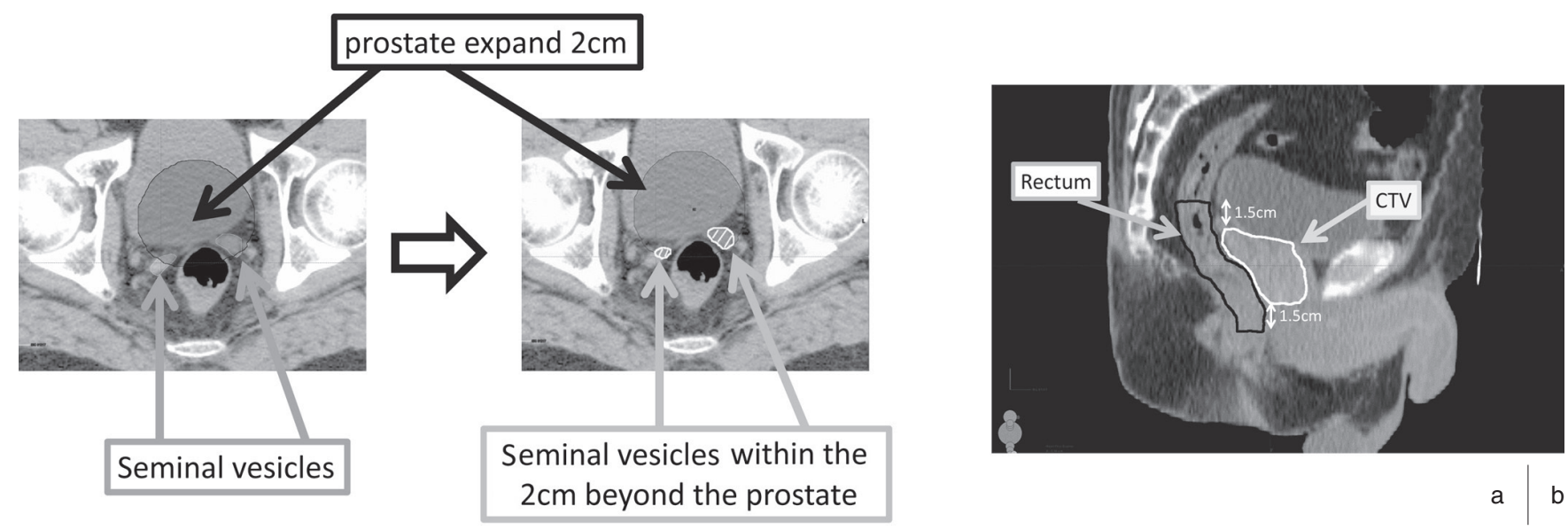

Fig. 1 Delineation of the target volume and organs.

(a) CTV includes the seminal vesicles within the $2 \mathrm{~cm}$ beyond the prostate.

(b) Rectum was contoured on the slices within $1.5 \mathrm{~cm}$ from the CTV edge in the craniocaudal direction.

CTV から頭尾方向に6スライス，つまり $1.5 \mathrm{~cm}$ の領域 を囲んだ体積とした[Fig. 1(b)]．直腸壁および膀胱壁は 各々の外部輪郭から内側に $4 \mathrm{~mm} の$ 厚さまでの体積と した．XiOではドーナツ状の構造体を認識しないため, 元々の構造体である直腸および膀胱から $4 \mathrm{~mm}$ 狭めた構 造体を作成した後に dose volume histogram $(\mathrm{DVH})$ 上で 元々の構造体と引き算処理することによって直腸壁およ び膀胱壁の評価を行った，CT 画像およびストラクチャ セットについては, digital imaging and communication in medicine in radiotherapy (DICOM RT) 機能を利用し, 輪 郭描出を行ったRTPS からその他 RTPS へ転送するこ とで同一の CT 画像拉よびストラクチャセットを使用し た治療計画を行うことが可能である，ただし，RTPSに よって CT 画像とストラクチャセットの表示ボクセル認 識が異なるため, 最大で 1 ピクセルずれが生じる。本 研究で使用した CT 画像の FOV が 500 mm であるため 最大 $1 \mathrm{~mm}$ 程度の誤差が生じるものとする.

2-1-2 インバースプランニングおよび線量評価に 用いた輪郭

本研究での処方線量は, PTV から直腸との重なり部 分を引いた体積である PTV excluding rectum の容積の 95\%を包含する線量(D95)を 76 Gy とした ${ }^{11)}$. IMRTの 治療計画では, 最適化計算アルゴリズムによる逆方向 治療計画(インバースプランニング) と称する治療計画手 法が用いられ，理想的な線量分布を得るためのフルエ ンスマップを作成する。一般的に最適化計算アルゴリ ズムには勾配法が用いられ, 臓器ごとに設定された目 標線量の達成度は, コスト関数を用いて計算される。 こ うして臟器ごとに計算された後に，それぞれのコストを 集計することで全体のコストとして評価される，そのた め, PTV と OARが重なり合った領域においてコスト関
数の奪い合いが起こることが知られている. そこで, PTV と OARの臟器以外の構造体として線量制限に矛 盾が生じることがないように擬似的構造体の設定を 行った。擬似的構造体としては, 直腸の後ろ半分から 外輪郭までの領域にかけて back avoidance とし, PTV と直腸の重複領域を overlap という構造体として追加描 出した，その他，Pinnacleでは骨盤腔内より外側の正常 組織に対する中程度線量領域の拡がりを防ぐため, 外 輪郭より PTV から $3 \mathrm{~cm}$ 拡大した体積を引き算した擬 似的構造体である pseudo-structure(Fig. 2) および直腸 から overlap 領域を引いた体積である rectum- PTVの追 加描出を行った。各 RTPS で使用した擬似的構造体を Table 2 に示す.

\section{2-2 前立腺 IMRT 治療計画}

治療計画に用いたガントリー角度は $0 ， 55 ， 105$, 155，205，255，305 度の 7 門である。 ガントリー角度 155, 205 度の角度に拈いて, 治療寝台を通過するビー ムが含まれるため X 線吸収による線量低減が考えられ る.XiO 以外の RTPS については寝台吸収を加味した 治療計画を行った，各症例に扔けるアイソセンタ，ガン トリー角度，コリメータ角度は同一とした。次にCTV, PTV, PTV excluding rectumの最小線量, 最大線量な らびに直腸，膀胱の耐容線量に基づく最適化線量制限 パラメータ設定を行った. Eclipseを用いたIMRT 計画 では, 各構造体に対する最適化線量制限パラメータの 重み付けとして priority 值を用いることができ，0〜 1000 までの值を割り振ることが可能である。本研究で は各構造体における重要度の比率を考慮したうえで priority 值の初期設定值基準を 100 , 最大值 150 まで使 用した. Pinnacleでは最適化線量制限パラメー夕の重 


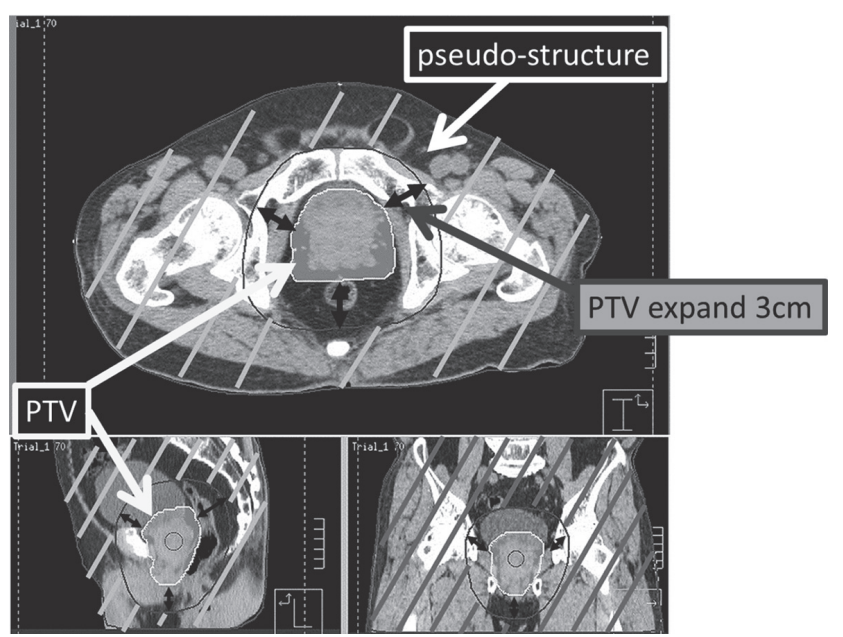

Fig. 2 Region of interest for dummy.

A pseudo-structure from which a 3-cm area enlarged beyond the outline of the PTV has been subtracted to prevent the spread of the medium dose area to normal tissue beyond the pelvic cavity.

み付けとして weight を用いることができ, 最大 100 ま で使用可能である。1 100 までで不足する場合には同一の パラメータを複数設定することによって, より大きい值 の入力が可能である。 また, Pinnacle 特有の最適化線 量制限パラメータとして uniform dose と呼ばれる機能 がある。これは任意の構造体の均一性を高めたい場合 に用いることが可能なものである，XiOでは, weight と powerの 2 種類で重み付けを行うことが可能である. 設定值を細かく調整したい場合には weight，大まかに 調整したい場合には powerを用いることが可能であ る. iPlanでは，重み付けを行うパラメータとしては構 造体のタイプ選択，もしくは hard constraint の有無にあ たる。また，iPlanでは，最適化線量制限パラメータの 設定を行った後に最適化計算が始まり 4 種類の治療計 画が自動立案される。本研究で治療計画評価に用いた 計画は, OAR lowもしくはOAR medium とした，最適 化線量制限パラメー夕設定においては，各 RTPSによっ て設定項目が異なるため統一したパラメー夕を使用する ことはできない．本研究で使用した各 RTPSによる初期 最適化線量制限パラメー夕設定值を Table 3 に示す。ま た，各RTPSに扔けるリーフセグメンテーション時のパ ラメータとして, 治療計画を行う以前に各 RTPSに登録 されたビームデー夕を使用し，前述のビームデー夕時の コミッショニングと同様，線量検証において実測誤差 2\%以内を担保できる範囲の值を使用した。

\section{2-3 治療計画評価}

まず，当院の線量制約 (Table 4)を満たしているかの
Table 2 Region of interest for dummy

\begin{tabular}{|c|c|}
\hline RTPS & Dummy structure name \\
\hline Eclipse & overlap \\
\hline & back avoidance \\
\hline \multirow[t]{3}{*}{ Pinnacle } & rectum-PTV \\
\hline & back avoidance \\
\hline & pseudo-structure \\
\hline $\mathrm{XiO}$ & back avoidance \\
\hline iPlan & back avoidance \\
\hline
\end{tabular}

RTPS: radiation treatment planning systems

評価を行った。続いて線量制約以外にPTV, PTV excluding rectum の平均線量, 最小線量についても評価 を行った。その他に線量均一性(homogeneity index: $H I$ )，線量集中性 (conformity index: $C I$ ) および目視によ る線量分布を確認することでローカルホットスポット (処方線量の $106 \%$ 以上の線量)およびコールドスポット (処方線量の $90 \%$ 以下の線量)がどのような箇所で発生 しているのか評価した.

HIについては, PTV excluding rectum, PTVの最大 線量と最小線量の比とした，算出式を示す。

$H I=\frac{\text { MaxDose }}{\text { MinDose }}$

CIについては, 次式から算出した12).

$C I=\frac{V_{p_{i}}}{V_{t}}$

$V_{p i}$ は処方線量で囲まれる体積, $V_{t}$ は標的体積とし, 本研究で評価に用いた標的体積はPTV excluding rectumとした，CIは1.0に近い場合に線量収束性が高 い.それぞれの数值評価項目については，対応関係に あるデータの検定方法であるウィルコクソン符号付順位 検定を用いて有意差検定を行った。

\section{3. 結 果}

CTV, PTV, PTV excluding rectum, 直腸, 直腸壁, 膀胱, 膀胱壁の DVH 結果の一例を Fig. 3 に示す。ま た，各RTPS を用いた前立腺 IMRT15 症例における直 腸抢よび膀胱の平均 DVH 結果を Fig. 4 に示す。ささら に，治療計画の結果を Table 5 に示す. Fig. 3(a)に示す CTV の DVH において肩の部分が急峻(CTV に対して最 も均一に照射されている計画)であるのはiPlan, 次に Pinnacle，そして Eclipse，XiOの順番となった. Fig. 3(b) に示すPTVのDVHでは, Pinnacle が最も急峻であ 
Table 3 Dose-volume constraints used in the planning

(a) Eclipse

\begin{tabular}{|c|c|c|c|c|}
\hline & & VOI $(\%)$ & cGy & Priority \\
\hline \multirow[t]{2}{*}{ CTV } & upper & 0 & 8050 & 80 \\
\hline & lower & 100 & 7900 & 100 \\
\hline \multirow[t]{3}{*}{ PTV excluding rectum } & upper & 0 & 8000 & 130 \\
\hline & lower & 100 & 7800 & 80 \\
\hline & lower & 98 & 7850 & 100 \\
\hline \multirow[t]{2}{*}{ PTV } & upper & 0 & 8000 & 100 \\
\hline & lower & 98 & 7850 & 100 \\
\hline \multirow[t]{2}{*}{ Overlap } & upper & 0 & 7700 & 90 \\
\hline & lower & 100 & 7000 & 50 \\
\hline \multirow[t]{5}{*}{ Rectum } & upper & 0 & 7850 & 70 \\
\hline & upper & 3 & 7300 & 90 \\
\hline & upper & 17 & 6000 & 110 \\
\hline & upper & 37 & 4000 & 70 \\
\hline & upper & 60 & 2000 & 50 \\
\hline \multirow[t]{3}{*}{ Bladder } & upper & 0 & 8000 & 20 \\
\hline & upper & 20 & 6000 & 40 \\
\hline & upper & 40 & 4000 & 40 \\
\hline Back avoidance & upper & 0 & 3700 & 65 \\
\hline
\end{tabular}

VOI: volume of interest

(c) $\mathrm{XiO}$

\begin{tabular}{lcccrrrr}
\hline \hline & Type & Rank & Objective & Dose (cGy) & Volume (\%) & Weight & Power \\
\hline CTV & target & 1 & maximum & 8170 & 0 & 600 & 2.5 \\
& & & minimum & 7900 & 100 & 300 & 2.4 \\
PTV excluding rectum & target & 1 & maximum & 8170 & 0 & 600 & 2.5 \\
& & & minimum & 7750 & 100 & 500 & 2.2 \\
Rectum & \multirow{2}{*}{2} & maximum & 7900 & 0 & 300 & 2.1 \\
& & & dose volume & 7300 & 3 & 200 & 2.0 \\
& & & dose volume & 6000 & 20 & 300 & 2.0 \\
& & & dose volume & 5000 & 28 & 150 & 2.1 \\
& & & dose volume & 4000 & 40 & 300 & 2.0 \\
Back avoidance & & & dose volume & 2320 & 60 & 300 & 2.0 \\
Bladder & & 3 & maximum & 3700 & 0 & 300 & 2.0 \\
& OAR & 4 & maximum & 8150 & 0 & 500 & 2.2 \\
& & & dose volume & 2750 & 35 & 300 & 2.0 \\
\hline
\end{tabular}

(d) iPlan

\begin{tabular}{lcccc}
\hline \hline & Type & $\begin{array}{c}\text { Volume } \\
(\%)\end{array}$ & $\begin{array}{c}\text { Dose } \\
(\mathrm{cGy})\end{array}$ & $\begin{array}{c}\text { Hard } \\
\text { constraint }\end{array}$ \\
\hline PTV & PTV & 0 & 8132 & $\checkmark$ \\
& & 50 & 7828 & \\
Rectum & 100 & 7600 & $\checkmark$ \\
& OAR3 & 0 & 7700 & \\
& & 3 & 7300 & \\
& & 13 & 5950 & $\checkmark$ \\
Back avoidance & OAR3 & 0 & 3550 & $\checkmark$ \\
Bladder & & 79 & 3200 & \\
& & 71 & 1800 & \\
& OAR3 & 0 & 7800 & \\
& & 8 & 5800 & \\
& & 27 & 3100 & \\
& & 70 & 1250 & \\
& & & &
\end{tabular}

(b) Pinnacle

\begin{tabular}{lcccr}
\hline \hline & Type & $\begin{array}{c}\text { Target } \\
\text { cGy }\end{array}$ & $\begin{array}{c}\% \\
\text { volume }\end{array}$ & Weight \\
\hline CTV & max dose & 8000 & - & 100 \\
PTV excluding & min dose & 7950 & - & 70 \\
rectum & max dose & 8000 & - & 100 \\
& min DVH & 7975 & 98 & 85 \\
& min dose & 7970 & - & 80 \\
PTV & max dose & 8000 & - & 15 \\
& min dose & 7200 & - & 100 \\
Rectum & max DVH & 7300 & 1 & 20 \\
Rectum-PTV & max DVH & 6000 & 0 & 10 \\
& max DVH & 4000 & 20 & 20 \\
Bladder & max DVH & 2000 & 40 & 1 \\
& max DVH & 6000 & 20 & 15 \\
Back avoidance & max DVH & 4000 & 40 & 1 \\
Pseudo-structure & max DVH & 3700 & 0 & 30 \\
& max DVH & 2800 & 0 & 30 \\
\hline
\end{tabular}

Table 4 Dose constraint for prostate cancer IMRT

\begin{tabular}{lc}
\hline \hline Structure & Constraint \\
\hline PTV excluding rectum & D $95=100 \%$ \\
& max dose $<110 \%$ \\
CTV $100 \%$ & $\geq 99.5 \%$ \\
Rectum volume & V40 Gy $\leq 50 \%$ \\
& V60 Gy $\leq 25 \%$ \\
& V70 Gy $\leq 15 \%$ \\
& V75 Gy $\leq 5 \%$ \\
Rectum wall & V40 Gy $\leq 65 \%$ \\
& V60 Gy $\leq 35 \%$ \\
Bladder volume & V70 Gy $\leq 25 \%$ \\
Bladder wall & V40 Gy $\leq 50 \%$ \\
& V65 Gy $\leq 25 \%$ \\
& V40 Gy $\leq 65 \%$ \\
& V70 Gy $\leq 35 \%$ \\
\hline
\end{tabular}


り, 次にiPlan, そしてEclipse, XiOの順番となった。

Fig. 3(c)に示す PTV excluding rectum についてもPTV と同様の結果となった. Fig. 3(d)に示す直腸の DVH 形 状はRTPSによって特徵的な結果となった. Eclipseで は低線量領域から高線量領域にかけて直線的な DVH 形状となった. Pinnacleでは直腸全体に $10 \mathrm{~Gy}$ 以上の 線量が照射され，そこから $30 \mathrm{~Gy}$ までの DVH 形状は 急峻であり, その後 $40 \mathrm{~Gy}$ 以上の線量領域から緩やか な DVH 形状となった，XiOでは，Pinnacle 以上に低線 量領域における直腸全体に照射される体積は増加する 傾向となった。 しかし， $60 \mathrm{~Gy}$ 以上が照射される体積に ついては他の RTPS より急峻な DVH 形状となった. iPlan では他の RTPS より 20〜30 Gy の線量領域におい て多くの直腸体積が照射されるのに対して 40〜60 Gy の線量では他の RTPS と比べ急峻な DVH 形状となっ た．Fig. 3(e)に示す直腸壁では直腸の DVH 形状と比較 し，60 Gy までの線量においてRTPS 間の差が顕著で あった. Fig. 3(f)に示す膀胱および Fig. 3(g)の膀胱壁につ いては直腸および直腸壁と比較し，特徴的な DVH 形状 は認めらなかった，唯一，特徵的なものを挙げるならば, 膀胱壁に対する線量において Pinnacleでは他の RTPS と 比較し照射される体積が多かった．Fig. 4(a)〜 (d)に示 す直腸の平均 DVH 結果 (エラーバーは標準偏差を示す) から, Eclipse 㧍よびXiOでは他の RTPS と比較し, 40 Gy 以上の線量領域において DVH 形状のばらつきが少 ない傾向となった．いずれの RTPS についても $60 \mathrm{~Gy}$ 以 上の線量領域に扮いて, それ未満の線量領域と比較 し，ばらつきが少ない傾向となった．Fig. 4(e)〜 (h) に示 す膀胱の平均 DVH 結果(エラーバーは標準偏差を示 す)から，直腸と比較し，いずれの RTPS でも DVH 形 状のばらつきが大きい傾向となった．DVH 形状のばら つきが最も少ない RTPS はPinnacle，次にXiO，そして Eclipse, iPlanの順番となった.

Table 5(a)から CTVでは Pinnacle の 1 症例のみ処方 線量の $100 \%$ が照射される容積(V100\%)が $99.36 \%$ と なったが，その他の RTPS ではいずれの症例でも当院 の線量制約(V100\%， $99.5 \%$ 以上)を順守可能であ り，症例ごとの違いも少ない結果となったＰTVにお ける最低線量を比較した場合, 最も線量が高くなった のは Eclipseの 59.23 \pm 5.51 Gy であり, 次に Pinnacle の

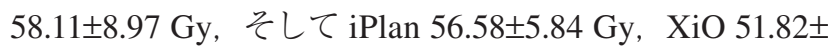
$6.63 \mathrm{~Gy}$ の順番であり, 症例ごとのばらつきは Pinnacle が最も大きくなった，平均線量については，いずれの RTPS に扔いても $77 \mathrm{~Gy}$ 後半〜 78 Gy 程度の線量を担 保しており，症例ごとの線量のばらつきも少ない結果と なった．また，HIにおいては最低線量の比較時と同様
にEclipseの結果が最もよく, 次にPinnacle, そして iPlan, XiOの順番となった. PTV excluding rectum で は, 最大線量が最も低い傾向であったのはiPlanの

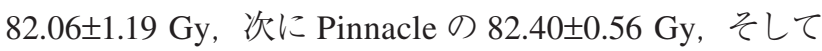
Eclipse $82.42 \pm 0.58 \mathrm{~Gy}, \mathrm{XiO} 82.98 \pm 0.46 \mathrm{~Gy}$ の 順番と なった，平均線量についてはPTV と同様にいずれの RTPS でも症例ごとの線量のばらつきは少なかった。最 低線量を比較した場合に最も線量が高くなったのは $\mathrm{XiO}$ の 66.21 $\pm 2.57 \mathrm{~Gy}$, 次に Pinnacle の 65.19 $\pm 2.84 \mathrm{~Gy}$,

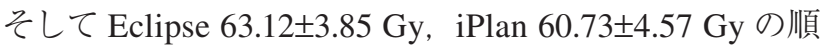
番となり, 症例ごとの線量のばらつきについても同様の 結果となった. HIでも最低線量の結果同様に最も線量 の均一性がよかったのはXiO, 次にPinnacle, そして Eclipse, iPlanの順番となった，CIの結果から Eclipse とiPlanに抢ける線量集中性は同等であり, Pinnacle, $\mathrm{XiO}$ の順番によい結果となった，直腸では $75 \mathrm{~Gy}$ 以上 照射される体積(V75 Gy)，5\%以下の線量制約を除け ば，全症例において線量制約を順守することが可能で あったＶ75 Gy，5\%以下の線量制約を満たすことがで きなかった症例は Pinnacle, iPlan 共に6例であった。 直腸壁，膀胱および膀胱壁については，いずれの症例 においても線量制約を満たすことが可能であった。

Table 5(b)に示すウィルコクソン符号付順位検定結果か ら直腸壁の $70 \mathrm{~Gy}$ 以上照射される体積 (V70 Gy) 以外の 評価項目については，RTPS 間で何かしらの有意差があ るとの結果となった

目視による線量分布評価に拀いてローカルホットス ポットが出現する特徵的な線量分布図を Fig. 5 に示 す. Eclipse では CTV と PTV excluding rectum の左右 方向もしくは，前方の中間～辺縁領域においてローカル ホットスポットが出現する傾向となった. Pinnacleでは PTV excluding rectum の頭側もしくは尾側に出現する傾 向であり，XiOでは CTV の中にはあるが，直腸近傍に 出現する傾向となった. iPlan では, Eclipse と同様の結 果となった.コールドスポットについては，いずれの RTPSに执いてもPTV の辺縁領域で出現した.

\section{4. 考 察}

前立腺 IMRT 計画においては, CTV から PTV マー ジンを付加させた場合に必ず直腸と重なり合う体積, すなわち, overlap 領域が発生する。そそのため, 直腸の 耐容線量の中でも 60〜 75 Gy の線量制約を順守しなが ら PTVに対して, いかに線量均一性と線量集中性を担 保していくのかが最適な治療計画を立案するために重 要であると考える．PTV と直腸が重なり合う overlap 領 域の最低線量を低く計画することで直腸へ照射される 

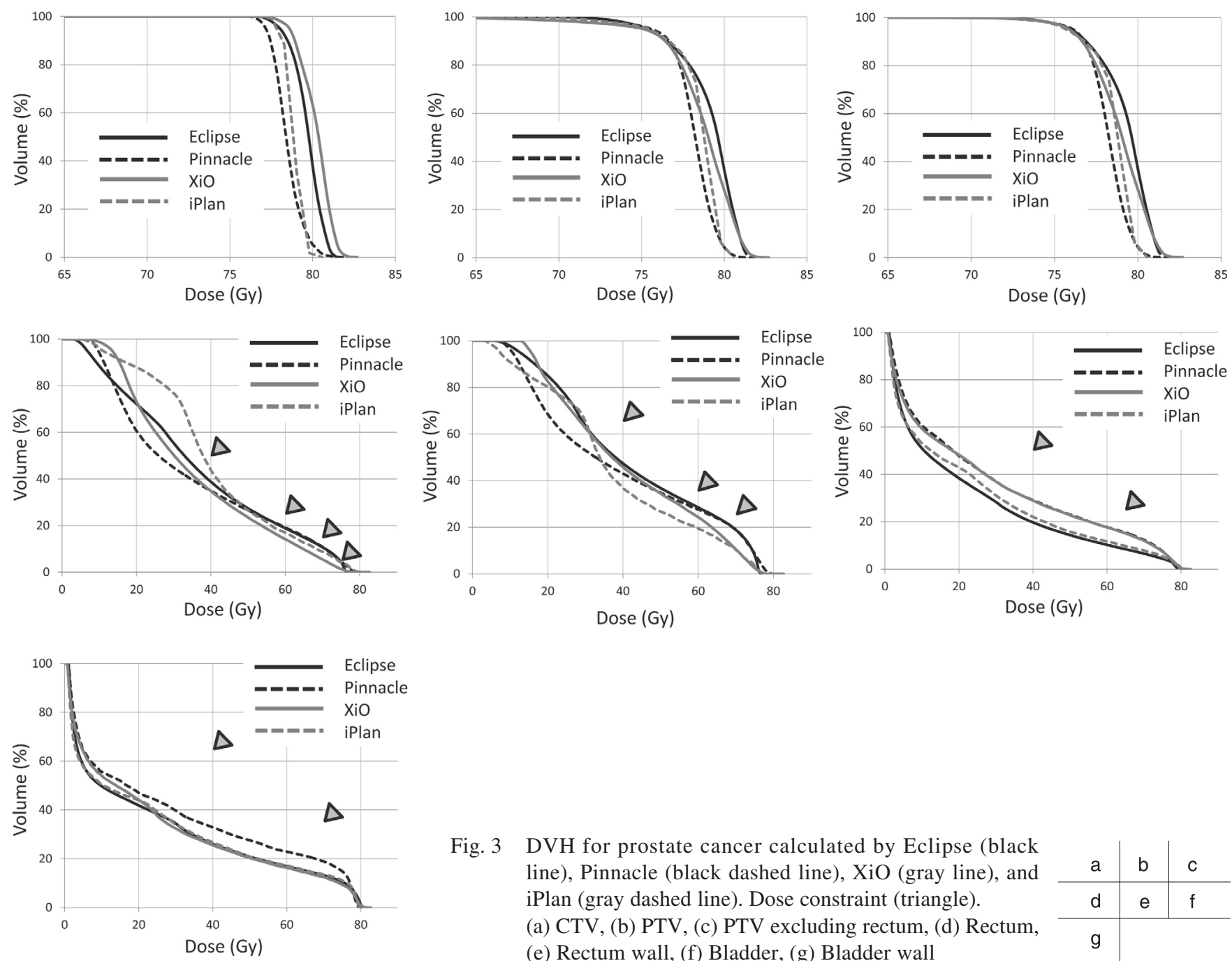

Fig. 3 DVH for prostate cancer calculated by Eclipse (black line), Pinnacle (black dashed line), XiO (gray line), and iPlan (gray dashed line). Dose constraint (triangle).

(a) CTV, (b) PTV, (c) PTV excluding rectum, (d) Rectum,

(e) Rectum wall, (f) Bladder, (g) Bladder wall

\begin{tabular}{l|l|l}
$a$ & $b$ & $c$ \\
\hline$d$ & $e$ & $f$ \\
\hline$g$ & \multicolumn{2}{|l}{}
\end{tabular}

$60 \mathrm{~Gy}$ 以上の体積を減らすことが可能であるが，減らし 過ぎた場合にはPTVのDVH の肩が緩やかとなり, 線 量均一性の悪い計画となる, そのため, 最適な治療計 画を行ううえでは, いかに overlap 領域の線量勾配をつ けるかが鍵となる. Fig. 4(a)〜 (d) に示す直腸の平均 DVH 結果から $60 \mathrm{~Gy}$ 以上の線量領域，すなわち直腸前 壁と後壁の 3 分の 1 前方までの領域に扔いては, RTPS ごとでの症例による違いは少ないと考える. また，当院 の線量制約であるV75 Gy，5\%以下について Pinnacle, iPlan 共に 6 症例で満たすことができなかったが, 最大 で $7.5 \%$ であため概ね直腸に対する線量低減を図る計 画立案が可能であったと考える。一方, PTVの最小線 量では XiO 以外の RTPS 間で有意差のない結果となっ たが，これは，XiOに扮ける最適化線量制限パラメー タとして直腸の $60 \mathrm{~Gy}$ 以上照射される体積を減らすこ とを目的として PTVを用いず, PTV excluding rectum を使用したためであると考える。前述した overlap 領域 の線量低減を図ることで直腸の高線量領域を減らすこ とができたが，その一方で PTVの最小線量が低くなっ
たと考える.

IMRT では一般的に処方線量として PTV の D95 もし くは平均線量が用いられている13). しかし，D95 処方に よる治療計画では, 線量のノーマライズを行うことに よって最低線量が低い場合には時として最大線量が大 幅に増加する計画となる可能性がある。過去の報告7で は，PTVの最大線量がRTPSによっては処方線量の最 大 $20 \%$ 程度生じる症例も報告されており，RTPS 間によ る違いが大きかったと報告されている。本研究では，い ずれの RTPS でも最大線量として $10 \%$ を超えるような 治療計画は 1 例もなかった。 しかし, 当院の線量制約に 基づき評価を行った結果 CTV, PTV, PTV excluding rectumの最大線量, 最低線量, 平均線量, $H I, C I$ に ついて各 RTPS 間による差は非常に少ないものであるが 有意差なしとの結果は得られなかった。 前立腺 IMRT 計画で得られる線量分布は PTV から直腸の背面方向側 に対して，処方線量の 90～60\%に至るまで 10\%ごとに $2 \mathrm{~mm}$ 程度ずつ広がる傾向である. しかし, 直腸が背腹 方向側へ広がっている症例については, PTVから直腸 

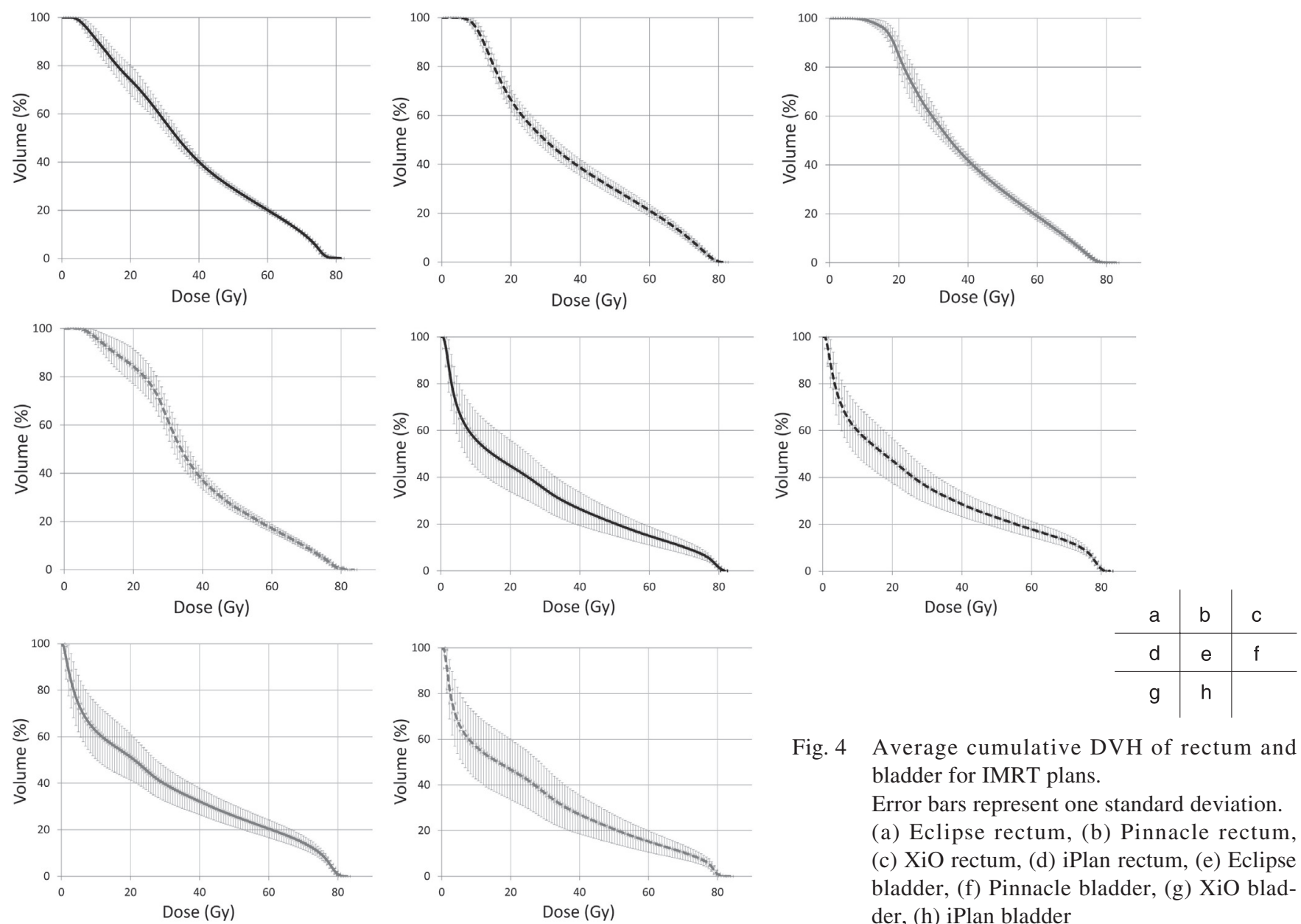

Fig. 4 Average cumulative DVH of rectum and bladder for IMRT plans.

Error bars represent one standard deviation. (a) Eclipse rectum, (b) Pinnacle rectum, (c) $\mathrm{XiO}$ rectum, (d) iPlan rectum, (e) Eclipse bladder, (f) Pinnacle bladder, (g) XiO bladder, (h) iPlan bladder

の背面方向側に対する線量分布の広がり方がRTPSに よって異なる傾向となった．各 RTPS で直腸の後ろ半分 から外輪郭までの領域にかけて back avoidance という 擬似的構造体を使用しているが，それぞれの最適化線 量制限パラメー夕自体が同一のものでないため, 一様の 線量制約を満たすことが困難であったと考える。また， 直腸が背腹方向に広がっている症例では, overlap 領域 において急峻な線量勾配が得られずとも線量制約を満 たす計画は可能である. Overlap 領域の線量において線 量分布が $2 \mathrm{~mm}$ 程度拡大もしくは縮小することによっ て, 直腸の V60 Gy 以上の線量制約と PTV などの最大 線量, 最低線量に有意差が生じたと考える. 膀胱につ いては, 症例ごとに膀胱蓄尿状態が異なるため, RTPS によって線量分布の集中性の違いが有意差ありとの結 果となったと考える.膀胱壁については, 膀胱と比較し て蓄尿状態による体積差が少ないため有意差が生じに くい結果となったと考える.

IMRTでは従来の放射線治療にない複雑な照射野を 用いた治療計画となるため PTV 内にローカルホットス ポットおよびコールドスポットが発生する可能性があ り, PTV 以外の場所についてもローカルホットスポット
が発生する可能性がある，DVHのみの評価では，それ らを見逃す可能性があるため, 注意深く線量分布を観 察する必要がある. Fig. 4 に示すローカルホットスポッ トの位置について，XiOでは CTV の中にはあるが，直 腸近傍に出現する線量分布であった。前立腺は, 直腸 内の便・ガス貯留抢よび膀胱の蓄尿状態によって大きく 移動するとの報告がある ${ }^{14)}$. そのため, 直腸近傍にロー カルホットスポットがあるような計画の場合には, 前立 腺が移動することによって, 実際の治療では直腸壁に 対してローカルホットスポットが出現する可能性がある ため, 患者固定法および画像誘導放射線治療が重要で あると考える。

本研究では, 治療計画評価のみの報告であり, 患者 固定法抢よび患者ごとにおける品質管理の言及は行っ ていないため，施設の実情に見合った物理的かつ臨床 的判断を追加検討する必要がある。また, IMRT 計画 では各 RTPSに扔いてインバースプランおよびリーフセ グメンテーションアルゴリズムなどさまざまな因子が複 雑にかかわり, それぞれで異なる仕様のため一様の比 較を行うことは困難である，そのため，本研究では，当 院の線量制約を満たすかどうかを評価すると共に DVH 


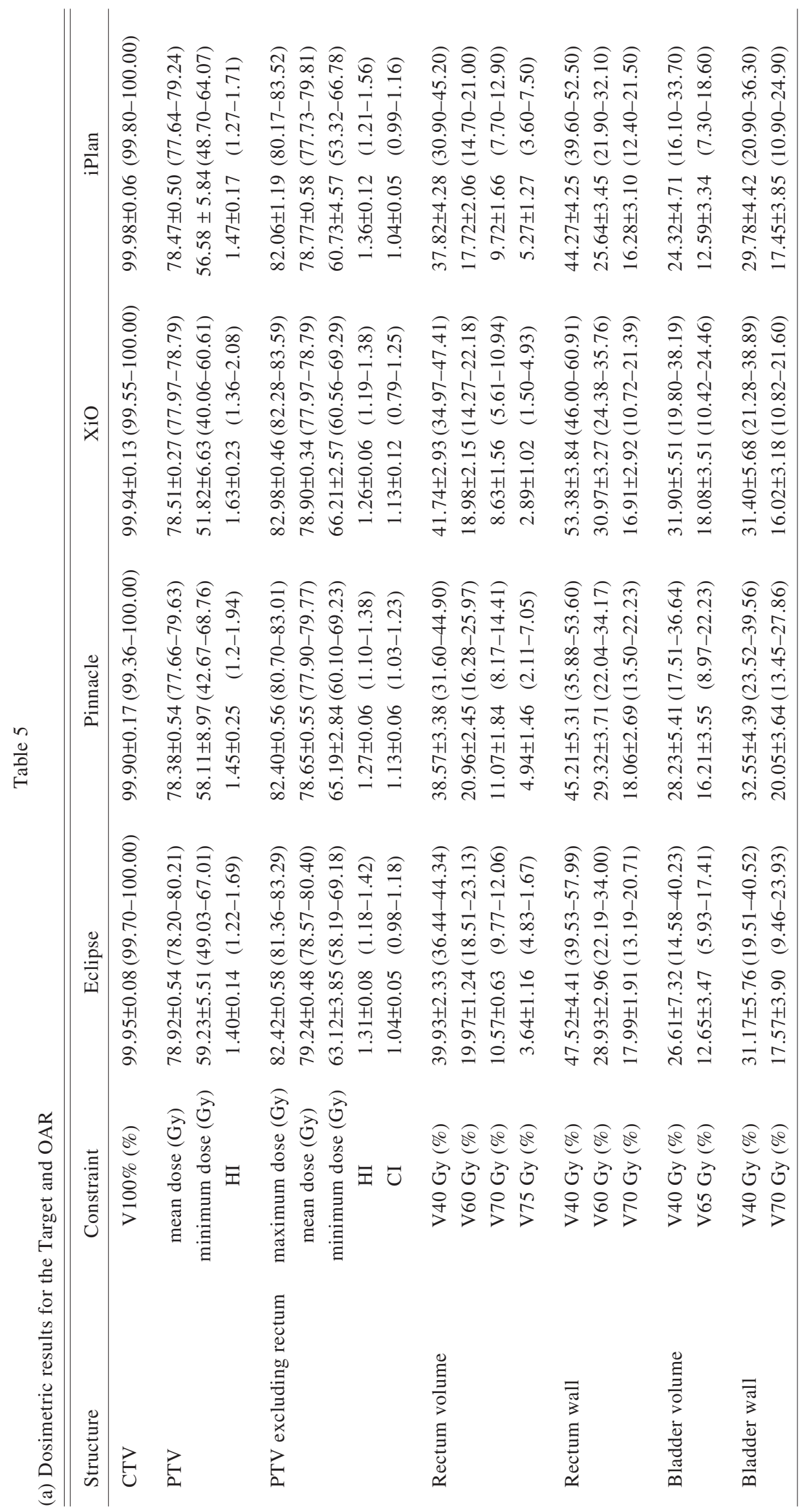




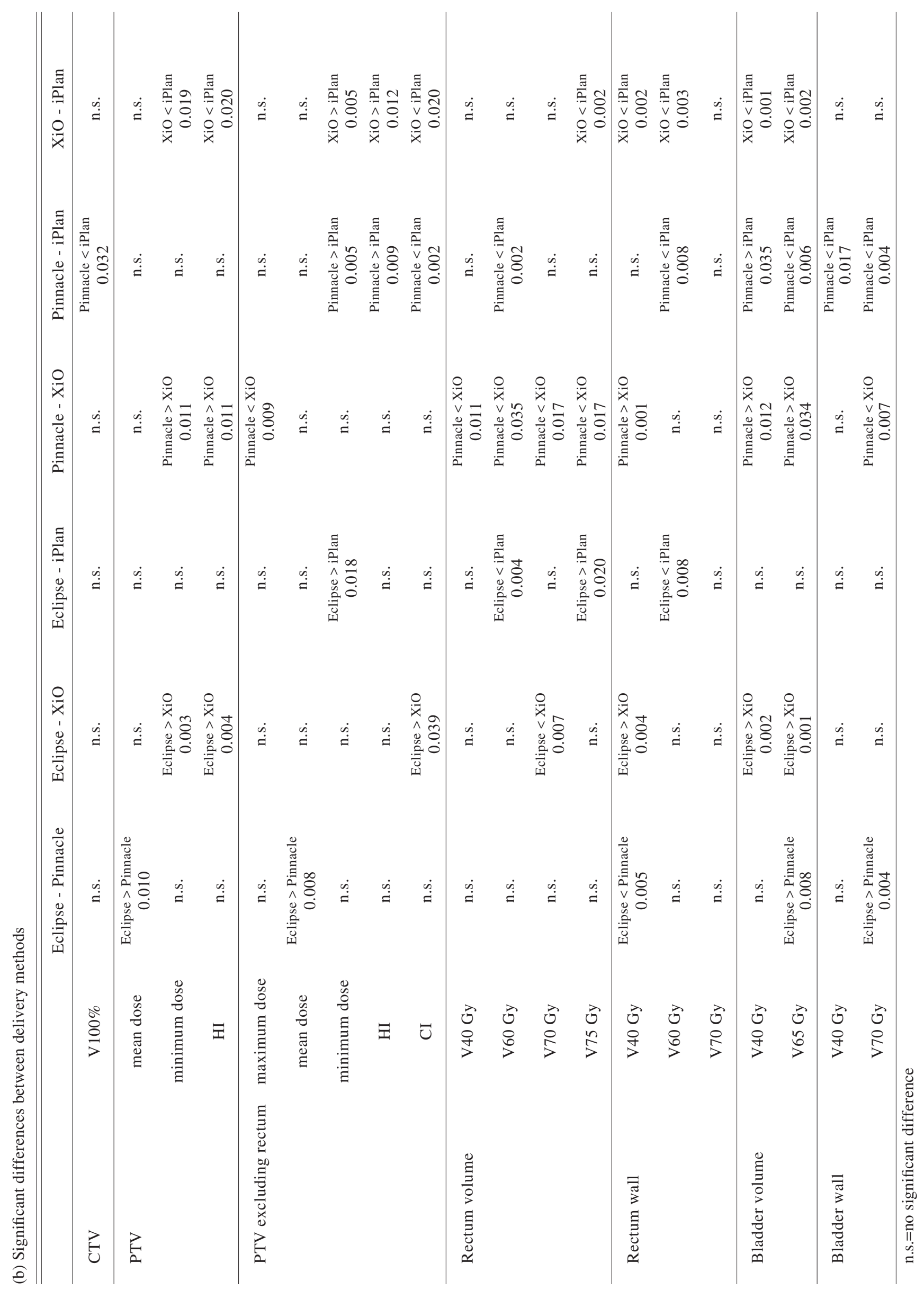



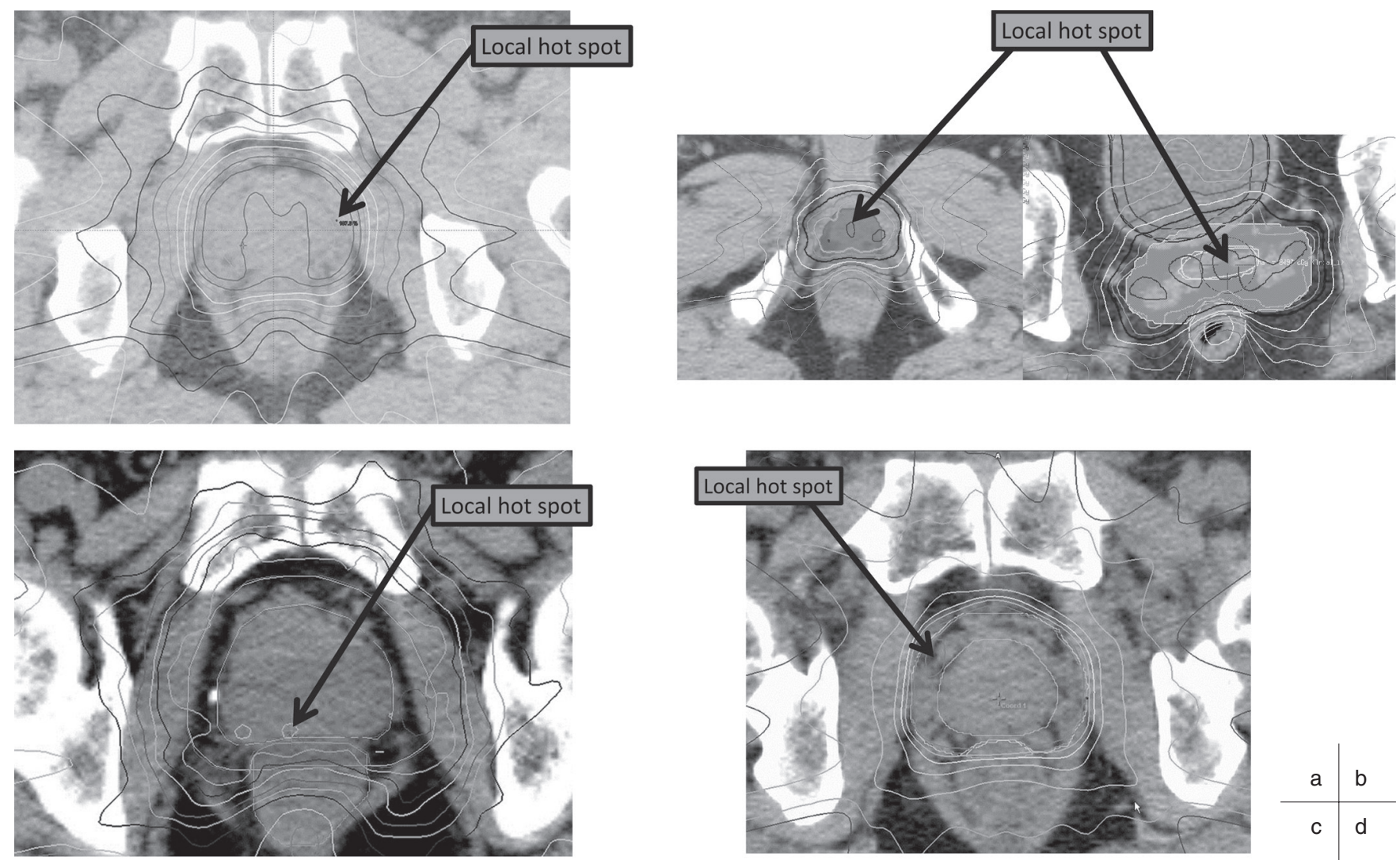

Fig. 5 Dose distribution of IMRT plans of a patient under study. (a) Eclipse, (b) Pinnacle, (c) XiO, (d) iPlan

形状の違いと線量分布の違いで評価を行ったものであ り，インバースプランおよびリーフセグメンテーション アルゴリズムの違いなどについては考慮していない．

国内においては，平成 20 年度の診療報酬改訂から頭 頸部腫瘍, 中枢神経腫瘍, 前立腺腫瘍に対して IMRT が保険適応となり, 平成 22 年度からは限局性固形悪性 腫瘍に対して適応とされている。前立腺 IMRTに関し て, 物理的な線量分布上の優位性から臨床成績の優位 性を示す報告は数多く行われている ${ }^{15 \sim 18)}$. これらのこと から多くの施設でIMRT が行われることとなり，今後ま すます普及される治療方法である。しかしながら施設に よって保有する放射線治療装置, RTPS が異なるため, 過去の報告を参考としながら施設独自の方法で治療計 画手法抢よび線量制約, PTV, OARの輪郭描出, 治療 装置やRTPS の品質管理が行われていると予想され る. 増加傾向にあるIMRT 治療計画において複数の RTPS で治療計画を立案し, 各 RTPS でどのような違い が現れるのか検討した本研究は重要であると考える. 本研究に抢ける前立腺 IMRT 計画は当院での線量制約
に基づいた限定的なものであるが，複数の RTPS を用 いた場合でも概ね順守することが可能であった。

\section{5. 結 論}

本研究では国内で販売されている代表的な 4 社の RTPS を用いた前立腺 IMRT 計画の比較検討を行っ た，その結果，当院に扔ける前立腺 IMRTの線量制約 をいずれの RTPSでも，概ね満たすことができたため， 同一の放射線治療装置を使用する場合には同様の治療 計画を立案することは可能である.

\section{謝 辞}

本研究にあたり，多大なご助言，ご協力を賜りました 株式会社バリアンメディカルシステムズアプリケーショ ングループ(現)バリアンメディカルシステムズ販売本部 販売支援部の原毅弘氏, 株式会社日立メディコ核医学 治療製品技術部の田中善子氏，エレク夕株式会社カス タマーサポート部の和田数幸氏, ブレインラボ株式会社 の田尻新吾氏に深く感謝致します。 


\section{参考文献}

1) Chui CS, Chan MF, Yorke E, et al. Delivery of intensitymodulated radiation therapy with a conventional multileaf collimator: comparison of dynamic and segmental methods. Med Phys 2001; 28(12): 2441-2449.

2) Intensity Modulated Radiation Therapy Collaborative Working Group. Intensity-modulated radiotherapy: current status and issues of interest. Int J Radiat Oncol Biol Phys 2001; 51(4): 880-914.

3) Petric MP, Clark BG, Robar JL. A comparison of two commercial treatment-planning systems to IMRT. J Appl Clin Med Phys 2005; 6(3): 63-80.

4) Bratengeier K, Meyer J, Flentje M. Pre-segmented 2-Step IMRT with subsequent direct machine parameter optimisation - a planning study. Radiat Oncol 2008; 3: 38-44.

5) Takahashi Y, Koizumi M, Sumida I, et al. What is the optimum minimum segment size used in step and shoot IMRT for prostate cancer? J Radiat Res 2010; 51(5): 543-552.

6) Fogliata A, Nicolini G, Alber M, et al. On the performances of different IMRT Treatment Planning Systems for selected paediatric cases. Radiat Oncol 2007; 2(7): 1-21.

7) Das IJ, Cheng CW, Chopra KL, et al. Intensity-modulated radiation therapy dose prescription, recording, and delivery: patterns of variability among institutions and treatment planning systems. J Natl Cancer Inst 2008; 100(5): 300-307.

8) ESTRO Physics booklet7 Quality Assurance of Treatment Planning Systems Practical Examples for Non-IMRT Photon Beams.

9) AAPM Report No.55 Radiation Treatment Planning Dosimetry Verification. Report of Task Group No.23 of the Radiation Therapy Committee of the American Association of Physicists in Medicine.
10) Boehmer D, Maingon P, Poortmans $P$, et al. Guidelines for primary radiotherapy of patients with prostate cancer. Radiother Oncol 2006; 79(3): 259-269.

11）柴田 徹. 近畿大学における取り組みと IMRT の標準化に 関する提言．臨放 2009; 54(5): 579-588.

12) 大西 洋, 平岡真寛監. 詳説 体幹部定位放射線治療 ガイドラインの詳細とマニュアル。 中外医学社, 東京, 2006: 74-81.

13) Mizowaki T, Hatano K, Hiraoka M. Surveillance on interfacility differences in dose-prescription policy of intensitymodulated radiation therapy plans for prostate cancer. $\mathrm{J}$ Radiat Res 2012; 53(4): 608-614.

14) Onishi H, Kuriyama K, Komiyama T, et al. Large prostate motion produced by anal contraction. Radiother Oncol 2012; 104(3): 390-394.

15) Zelefsky MJ, Fuks Z, Happersett L, et al. Clinical experience with intensity modulated radiation therapy (IMRT) in prostate cancer. Radiother Oncol 2000; 55(3): 241-249.

16) Kuban DA, Tucker SL, Dong L, et al. Long-term results of the M. D. Anderson randomized dose-escalation trial for prostate cancer. Int J Radiat Oncol Biol Phys 2008; 70(1): 67-74.

17) Zelefsky MJ, Levin EJ, Hunt M, et al. Incidence of late rectal and urinary toxicities after three-dimensional conformal radiotherapy and intensity-modulated radiotherapy for localized prostate cancer. Int J Radiat Oncol Biol Phys 2008; 70(4): 1124-1129.

18) Michalski JM, Bae K, Roach M, et al. Long-term toxicity following $3 \mathrm{D}$ conformal radiation therapy for prostate cancer from the RTOG 9406 phase I/II dose escalation study. Int J Radiat Oncol Biol Phys 2010; 76(1): 14-22. 